\title{
Synthesis of Isatin and Its Derivatives and their Applications in Biological System
}

\author{
Tariq Aziz ${ }^{1 *}$, Asmat Ullah ${ }^{2}$, Roh Ullah ${ }^{3}$, Fazal Haq ${ }^{4}$, Mudassir Iqbal', Farman Ullah Khan ${ }^{5}$, \\ Muhammad Imran Jamil ${ }^{1}$, Muhammad Raheel ${ }^{6}$ and Mehwish Kiran ${ }^{7}$ \\ ${ }^{1}$ College of Chemical and Biological Engineering, Zhejiang University, Hangzhou, China. \\ ${ }^{2}$ School of Pharmacy. Xian Jiaotong University Shannxi, China
}

${ }^{3}$ School of Chemistry and Chemical Engineering, Beijing Institute of Technology, China

${ }^{4}$ Department of Chemistry, Gomal University, Dera Ismail Khan, KPK, Pakistan

${ }^{5}$ Department of Chemistry, University of Science and Technology Bannu 28000, Pakistan/ Department of Chemistry, University of Lakki Marwat, Lakki Marwat 28420, KPK, Pakistan

${ }^{6}$ Baluchistan University of Information Technology, Engineering and Management Sciences (BUITEMS), Department of Chemistry. Baluchistan, Pakistan

${ }^{7}$ Department of Horticulture Gomal University, Dera Ismail Khan, KPK, Pakistan

*Corresponding author: Tariq Aziz, College of Chemical and Biological Engineering, Zhejiang University, Hangzhou, China

\begin{tabular}{|c|}
\hline ARTICLE INFO \\
\hline Received: 幽 September 11, 2020 \\
\hline Published: \\
\hline $\begin{array}{l}\text { Citation: Tariq Aziz, Asmat Ullah, Roh } \\
\text { Ullah, Fazal Haq, Mudassir Iqbal, et al. } \\
\text { Synthesis of Isatin and Its Derivatives and } \\
\text { their Applications in Biological System. } \\
\text { Biomed J Sci \& Tech Res 30(4)-2020. BJSTR. } \\
\text { MS.ID.004991. }\end{array}$ \\
\hline
\end{tabular}

MS.ID.004991.

\section{ABSTRACT}

Here investigations were made to study the variant developments in the synthesis of isatin and its derivatives. This review comprehended the various synthetic methods especially, sandmeyer synthesis, stolle synthesis and gassman synthesis for the synthesis of isatin. The isatin and its derivatives played a key role in biomedical applications. The isatin and its derivatives are used as bactericide, fungicide, anti-HIV, anti-epileptic, anti-instigative and so on. The isatin derivatives are helpful in inhibiting the activity of the urease and $\alpha$-glucosidase enzymes and reduce the risks of pyelonephritis, gastric problems and diabetes. This review highlighted the synthetic routes for the synthesis of isatin and the beneficial aspects of isatin and its derivatives in biomedical field.

Keywords: Isatin; Urease Inhibition; $\alpha$-Glucosidase Inhibition; Antioxidant Activity; Sandmeyer Synthesi

\section{Introduction}

Isatin is an indole derivative firstly synthesized in the laboratory by Erdmann and Laurent by oxidation of indigo pigment having chromic acid. It is orange-red in color with freezing point $200^{\circ} \mathrm{C}[1,2]$. Isatin is heterocyclic compound and acts as important species for the synthesis of various heterocyclic compounds especially, indolic and quinolinic compounds. It is also used in medicines synthesis (Figure 1). Thiosemicarbazide derivatives of isatin were reported as an anti-HIV agent [3]. N-methyl isatin$\beta$-4',4'-diethylthiosemicarbazone prove high inhibition of HIV by their action on contrary transcriptase and viral structural proteins [4]. 3-p-(p-(alkoxycarbonyl) phenyl) carbamoyl) phenyl) imino-1-aminomethyl-2-indolinones was by R.S Verma et al. was successfully tested against M. tuberculosis H37Rv [5]. Isatin derivatives are very effective against micro-organism especially, $S$ aureus, $S$ epidermis, Micrococcus luteus, and B cereus. The Schiff base of isatin derivatives 5-substituted and $\mathrm{N}$-acetyl isatin with different substituted aromatic aldehydes was assumed to be very operative against micro-organisms [6,7]. Bis-Schiff bases of isatin were found to possess significant anti-viral, antibacterial and antifungal activity $[8,9]$.

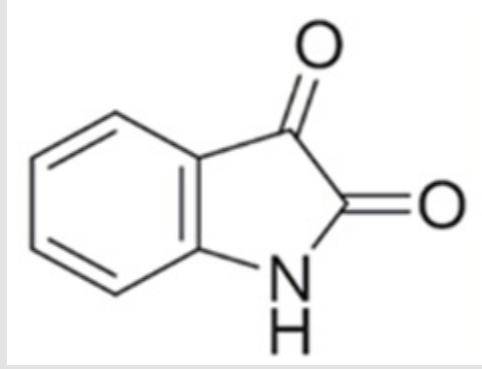

Figure 1: Skeleton of Isatin. 
The azetidine and thiadiazine derivatives of isatin were also found to possess significant antibacterial activity [10]. 5-Nitro1H-indole-2,3dione-3-N-(4H-methyl phenyl)thiosemicarbazones screened for antibacterial activity against E.coli and S.aureus by the cup-plate method and found active [11]. It also acts as anti-HIV, showing enzyme inhibition activity and as cytotoxic agent against tumor cells [12-14]. In antismall pox [15], inflammatory activities [16], kinase activator [17]. Also, biologically active on echinococcus multilocularis metacestodes [18]. Meshram et al. also developed an isatin-based multicomponent reaction for the synthesis of spirooxindole fused N-heterocyles with anticancer properties [19]. Zhang et al. first reported the vinylogous, henry reaction between isatin and 3,5-dialkyl-4-nitroisoxazole, leading to isoxazolesubstituted 3-hydroxy-2-oxindole derivatives, medicinally important compounds [20], also provided the basis for removal of industrial dye wastewater [21]. In this study, we discuss with detail "Synthesis of isatin and its derivatives and their applications in biological system" because isatin play a key effects like ascorbic acid, hydroxyl amino acids, omeprazole, thiol compounds and imidazole etc. which is helpful for the pathogenesis of gastric ulcer and peptic ulcer.

Also discuss antioxidants, which are responsible for converting free radicals into stable substances, especially serious diseases caused by diabetes. We can say, that isatin provides a critical and dynamic role in the pharmaceutical industry.

\section{Isatin Synthesis}

\section{Sandmeyer Synthesis}

One of the most famous techniques for the synthesis of isatin is Sandmeyer method. Aniline reacts with chloral hydrate and hydroxylamine hydrochloride conducting aqueous solution of sodium sulfate to produce an isonitrosoacetenilide. In this way, isonitosoacetenilide in the presence of sulphuric acid easily converted into isatin analogs [22] (Figure 2).



Figure 2: Synthesis of Sandmeier Isatin.

\section{Stolle Synthesis}

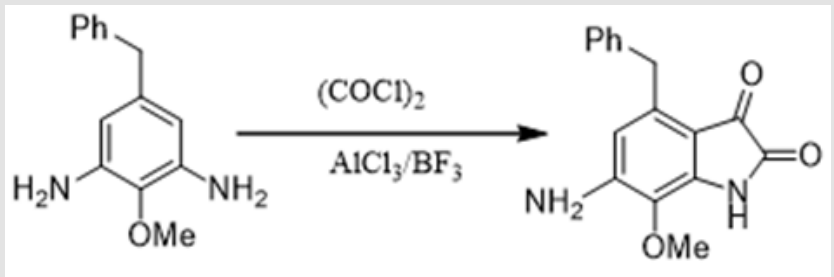

Figure 3: Stolle Synthesis of Isatin.

This method is very effective for the synthesis of isatin and its derivatives. The substituted isatin is synthesized by converting substituted aniline in the presence of oxalyl chloride and Lewis acids like $\mathrm{BF} 3$ or $\mathrm{AlCl}_{3}$. This method is also very useful to synthesize 1-Maryland polycyclic istan from phenothiazine, phenoxazine, dibenzoazepine and indol $[23,24]$ (Figure 3).

\section{Gassman Synthesis}

Gassman introduced a new approach, to synthesize isatin. This method involves the characteristics relationship between electrons donating, an electron withdrawing group, to convert aniline to intermediate 3-methylthyiooxidinol. In this intermediate, the methyl group is oxidized by N-chlorosucinamide, which is proceeded by the hydrolysis of the chlorinated intermediate $[25,26]$ (Figure 4).

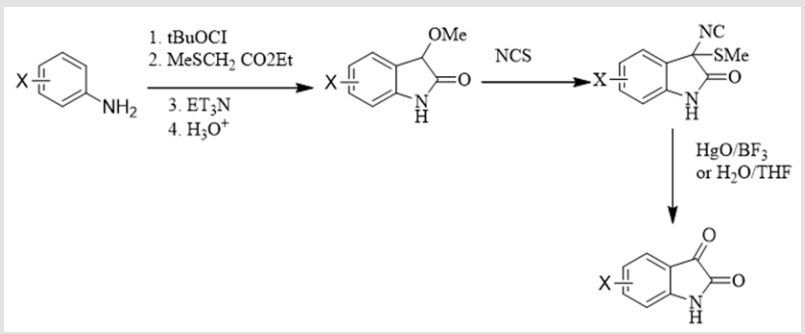

Figure 4: Gassman synthetic scheme for the synthesis of Isatin. 


\section{Isatin Derivatives}

Isatin derivatives are well known malleable substances, which are acted as forerunners for the synthesis of heterocyclic compounds [27]. Isatin derivatives play a vital role in the medicines because it used as bactericide [28], used for viral infections [29], anti-HIV [30], fungicide [31], anti-epileptic [32], anti-neoplastic [33], for the treatment of Mycobacterium [34] and anti- instigative [35]. Isatin derivative like 5-hydroxy isatin and spirobenzodiazepine, also used to reduce depression [36] (Figure 5). Few derivatives of isatin like 3-p-(p-(alkoxycarbonyl)phenyl)carbonyl)phenyl) imino-1-aminomethyl-2-indolinone is found to be effective against tuberculosis [37]. 5-[2(3)-dialkyl aminoalkoxy] Indole 2,3-dione is one of the important isatin derivative used against aminoalkane (histamine) [38]. Isatin derivatives are used for the treatment of malaria. 4-aminoquinoline derivatives were found to be efficacious versus Plasmodium falciparum [39]. Such derivatives can be obtained both from natural and synthetic source. tryptanthrin wellknown isatin derivative obtained from Chinese herb [40].

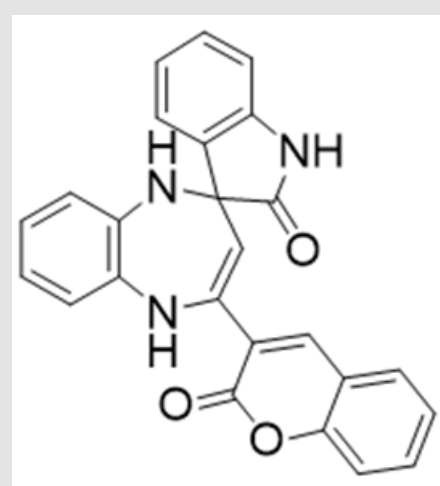

Figure 5: Structure of 5-hydroxy and spirobenzodiazepineisatin derivative.

Most of this type, derivatives are synthesized in laboratories, such as 5-methyl isatin [41], and 5-aminoindazole and mercaptoacetic acid can easily prepared [42]. By treating alkyl isatin with the compound labeled acidic medium (acetic acid) reflux at 2 hours is converted into 2-aminobenzoic acid (2-oxo-1,2 dihydro-indole3-ylidene)-hydrazide [43]. Synthesizes, compound involves so many synthetic routes. Then these compounds were dissolved in acidic (acetic acid) in water basic solution [44-48]. The synthesis of Schiff base isatin which is synthesized reacting substituted isatin compounds for a time period of 8-12 $\mathrm{h}$ in the presence of ethanol and glacial acetic acid [49]. Such synthesize compounds is also comprised of chain reactions. Obtaining, the said compound, substituted isatin was treated with 8-hydroxy indol compound by oxidation and reduction in the presence of acid $\left(\mathrm{H}_{2} \mathrm{SO}_{4}\right)$ and base $\left(\mathrm{C}_{2} \mathrm{H}_{5} \mathrm{OH}\right)$ [50]. Schiff base of isatin was prepared by the reaction of $\mathrm{N}$-methyl isatin with p-nitro-(chloro-, fluoro-, methoxy-, carboxy-,) aniline [51]. Mono and di-substituted xylenes have been prepared by the reaction of the potassium salt of 5 -bromoisatin with dihalo derivatives of $p$-, $m$ - and o-xylene in the presence of DMF and $\mathrm{K}_{2} \mathrm{CO}_{3}$ [52].

Aniline as starting material by treating with chloral hydrate through condensation could be converted into imesatin in the presence of $\mathrm{H}_{2} \mathrm{SO}_{4}, \mathrm{HCl}$, and $\mathrm{NH}_{2} \mathrm{OH}$. The isatin derivative could be prepared by reacting different aromatic aldehydes with imesatin in the presence of acetic acid and ethanol [53]. Isatin could be synthesized by treating, isatin 2 with 3 - substituted -4-amino-5mercapto-1, 2, 4-triazole on reflux in the presence of ethanol and addition of $\mathrm{HCl}$. Pure product was obtained by recrystallization from methanol $[54,55]$. Similarly, Schiff base of isatin could also be synthesized by refluxing (indol 2,3-dione) with (3-amino-5-phenylpyrazole) in acid-base media of ethanol and acetic acid [56]. The synthesis of the said compound is comprised of so many intermediate reactions. For this types of synthesis, first synthesized compound immediate hydrochloride, ester ethoxycarbonylhydrazone, and 4-amino-4,5-dihydro-1H-1,2,4-triazoles. After this, compounds were condensed with isatin in the existence of acetic acid, which is directly followed by the reaction of cyclopamine and formaldehyde [57]. The synthesis of Schiff bases, are prepared simply by reacting and refluxing aromatic di-amines with compound 2,4-diethoxy aniline in the presence of acid-base media [58]. Similarly, by refluxing benzyl isatin, aromatic diamines of acid-base media of ethanol and acetic acid with 5-Fluro isatin, the Bis-Schiff bases of isatin and its derivatives were also synthesized [59].

\section{Urease Inhibition}

Urea, which is well-known fertilizer used for the enhancement of fertility of the soil, urea contains (46\%) nitrogen. This urea release nitrogen in the form of ammonia gas due to which its action of fertility is also affected [60]. Urease is a well-known enzyme has nickel in their body structure which convert urea to carbon dioxide and ammonia by hydrolytic catalysis [61]. This typical enzyme is isolated by the same catalysis process from different plants, algae, fungi and bacteria [62,63]. As this enzyme has the same amino acid sequence and having $\mathrm{Ni}^{+2}$ in their core structure that is why its origin is very common $[62,64,65]$, and develop various types of diseases in animals and plants especially stomach and gastrointestinal ulcer, hepatic coma urolithiasis and pyelonephritis $[66,67]$. Recently two new isatin derivatives (1-allyl-2-oxoindolin3-ylidene)-4-methylbenezenesulfono-hydrazide and (1-allyl-2oxoindolin-3-ylidene)-4-chlorobenzenesulfono-hydrazide were synthesized with a high yields. The dynamic stability, reactivity, and affinity of these two derivatives are described. Enzyme inhibition potential test was carried out on urea enzyme of bacillus pasteurii urease and both compounds retarded the enzymatic activity with IC50 values of $39.46 \pm 0.12 \mathrm{mM}$ and $148.35 \pm 0.16 \mathrm{mM}$ respectively [68] (Figure 6). 


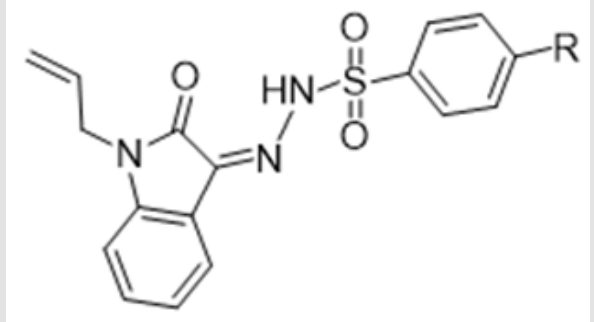

Figure 6: Derivative of isatin.

Helicobacter pyroli is the well-known bacterium which causes gastric and peptic ulcer [69]. This bacterium discharge urease which converts urea to ammonia which is basic in nature which increases the $\mathrm{pH}$ of the stomach and provides a good environment for their growth. This enzyme is very useful to eradicate the toxic organism from our body [70]. Recently, numerous urease enzymes have been added to literature especially triazoles and coumarin derivatives [71], Schiff bases derivatives [72], omeprazole [73], plan tool and its thiourea derivatives [74], hydroxamic acid [75], lansoprazole [76], thiol-compound [77], phosphorodiamidates $[78,79]$, imidazoles, for example, rabeprazole [80], hydroxyurea [81], quinine [82] and hydroxamic acid derivatives [83].

\section{$\alpha$-Glucosidase Inhibition}

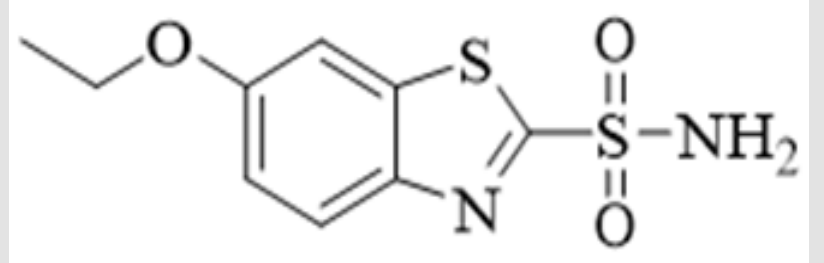

Figure 7: Structure of commercial drug containing benzothiazole.

$\alpha$-glucosidase is also regarded as exoglycosidase enzyme. This enzyme is present in the intestinal tract which hydrolyzed the carbohydrate and converted into glucose. This glucose is then entering the bloodstream and its excess causes postprandial hypoglycemia [84]. The main aim of the $\alpha$-glucosidase inhibitors is to delay the hydrolysis of carbohydrate to reduce the risks of diabetes [85], that's why this enzyme is preferably used in anti-diabetic medicines [86]. $\alpha$-Glucosidase inhibitors retard the function of $\alpha$-glusidase, which is responsible, to convert carbohydrate into glucose. So, in this, way it, reduces the glucose level in the blood stream and hemoglobin [87]. The main drawback of this enzyme is lack of specify in targeting glycosidase and causes infections especially relating to the stomach and intestines, looseness of the bowel and produce a state of excessive gas in the alimentary canal [88]. The derivatives of benzothiazole-triazole were synthesized, and their characterization was carried out with ${ }^{1} \mathrm{H}-\mathrm{NMR}$ and ${ }^{13} \mathrm{C}$-NMR. The inhibitory activity of $\alpha$-glucosidase inhibitory in vitro was screened by baker's yeast $\alpha$-glucosidase enzyme. Compared to standard IC $_{50} 817.38 \mu \mathrm{m}$ values between 20.7 and $61.1 \mu \mathrm{m}$, most compounds exhibit varying degrees of alpha-glucose inhibition activity (Figure 7).

\section{Antioxidant Activity}

Free radicals are atom or molecule with an odd electron in their outmost shell [89], are highly unstable and always in search to gain an electron from any species to complete its outermost shell in order to make itself stable. In our body, during the metabolism process of oxygen, any free radicals are generated in mitochondria. So, it is very important to eradicate these free radicals, if it is not so, they will cause different diseases especially malignant neoplastic disease, disease relating to the brain and the blood vessels, dotage, heart disease, ulceration, diabetes, heart disease, mucoviscidosis, agedness, gastrointestinal ulcer and acquired immune deficiency syndrome $[90,91]$. So, to overcome this problem antioxidants are used, because their main function is to convert these highly unstable free radicals to stable substances. Antioxidants are used in a large number of medicines which are used to cure the diseases caused by the free radicles [92-94]. Here also experimental and theoretical results, compatible with (H25MI3ClPT) and (H25MI3PT) concentration of free radical scavenging in DPPH. The proportionality increased in the antioxidant activity. In particular, it is theoretically confirmed that the antioxidant activity of DPPH products with high energy volume (H25MI3ClPT) -IC50 is lower than (H25MI3PT)-DPPH products [95].

\section{Conclusion}

In this paper, isatin and its derivatives were studied and evaluate their biological activates, such as urea enzyme inhibition, alphaglucosamine inhibition and antioxidant activity. Various synthetic methods especially, sandmeyer synthesis, stolle synthesis and gassman synthesis were discussed for the synthesis of isatin. The isatin and its derivatives played a phenomenal role in biomedical applications. The isatin and its derivatives are used as bactericide, fungicide, anti-HIV, anti-epileptic, anti-instigative and so on. The isatin derivatives are useful in constraining the natural action of the urease and $\alpha$-glucosidase enzymes and reduce the threats to human health like pyelonephritis, gastric problems and diabetes.

\section{Compliance with Ethical Standards}

Conflict of Interest: The authors declare that they have no conflict of interest.

Ethical Approval: This article does not contain any studies with human participants or animals performed by any of the authors.

\section{References}

1. Medvedev A, Buneeva O, Gnedenko O, Ershov P, Ivanov A, et al. (2018) Isatin, an endogenous nonpeptide biofactor: A review of its molecular targets, mechanisms of actions, and their biomedical implications. Biofactors 44(2): 95-108. 
2. Sumrra SH, Atif AH, Zafar MN, Khalid M, Tahir MN, et al. (2018) Synthesis, crystal structure, spectral and DFT studies of potent isatin derived metal complexes. J Mol Struct 1166(15): 110-120.

3. Havrylyuk D, Zimenkovsky B, Vasylenko O, Gzella A, Lesyk R, et al. (2012) Synthesis of New 4-Thiazolidinone-, Pyrazoline-, and Isatin-Based Conjugates with Promising Antitumor Activity. Journal of Medicinal Chemistry 55(20): 8630-8641.

4. Da Silva JFM, Garden SJ, Pinto AC (2001) The chemistry of isatins: a review from 1975 to 1999. J Braz Chem Soc 12(3): 273-324

5. Medvedev AE, Clow A, Sandler M, Glover V (1996) Isatin: A link between natriuretic peptides and monoamines? Biochemical Pharmacology 52(3): 385-391.

6. Bouhfid R, Joly N, Essassi EM, Lequart V, Massoui M, et al. (2011) Synthesis of New Spiro[1,4,2-dioxazole-5,3'-indolin]-2'-one by 1,3-Dipolar Cycloaddition. Synthetic Communications 41: 2096-2102.

7. Noori MS, O’Brien JD, Champa ZJ, Deosarkar SP, Lanier OL, et al. (2017) Phenylmethimazole and a thiazole derivative of phenylmethimazole inhibit IL-6 expression by triple negative breast cancer cells. European Journal of Pharmacology 803: 130-137.

8. Abdelhamid AO, Gomha SM (2017) Synthesis and characterization of new pyrazole-based thiazoles. Synthetic Communications 47: 14091414.

9. Ullah A, Mangi AA, Khan H, Khan B, Nawaz T, et al. (2019) Formulation of Loxoprofen Microparticles and it's In Vitro Characterization. Lat Am J Pharm 38(8): 1648-1659.

10. Fadda AA, Afsah ESM, Awad RS (2013) Synthesis and antimicrobial activity of some new benzo and naphthonitrile derivatives. Eur J Med Chem 60: 421-430.

11. Zelisko N, Atamanyuk D, Vasylenko O, Grellier P, Lesyk R, et al. (2012) Synthesis and antitrypanosomal activity of new 6,6,7-trisubstituted thiopyrano 2,3-d 1,3 thiazoles. Bioorg Med Chem Lett 22(23): 70717074

12. Nath Pandeya S, Smitha S, Jyoti M, Krishnan Sridhar S (2005) Biological activities of isatin and its derivatives Acta Pharm 55(1): 27-46.

13. Konkel MJ, Lagu B, Boteju LW, Jimenez H, Noble S, et al. (2006) 3-Arylimino-2-indolones Are Potent and Selective Galanin GAL3 Receptor Antagonists. Journal of Medicinal Chemistry 49(13): 3757 3758.

14. Matesic L, Locke JM, Bremner JB, Pyne SG, Skropeta D, et al. (2008) $\mathrm{N}$-Phenethyl and $\mathrm{N}$-naphthylmethyl isatins and analogues as in vitro cytotoxic agents. Bioorganic \& Medicinal Chemistry 16(6): 3118-3124.

15. C Pirrung M, V Pansare S, Das Sarma K, Keith K, R Kern E, et al. (2005) Combinatorial Optimization of Isatin- $\beta$-Thiosemicarbazones as Antipoxvirus Agents J. Med Chem 48(8): 3045-3050.

16. Sridhar SK, Pandeya SN, Stables JP, Ramesh A (2002) Anticonvulsant activity of hydrazones, Schiff and Mannich bases of isatin derivatives. European Journal of Pharmaceutical Sciences 16(3): 129-132.

17. Natarajan A, Fan Y-H, Chen H, Guo Y, Iyasere J, et al. (2004) 3,3-Diaryl1,3-dihydroindol-2-ones as Antiproliferatives Mediated by Translation Initiation Inhibition. Journal of Medicinal Chemistry 47(8): 1882-1885.

18. Paria S, Lee H-J, Maruoka K (2019) Enantioselective Alkynylation of Isatin Derivatives Using a Chiral Phase-Transfer/Transition-Metal Hybrid Catalyst System. Acs Catal 9: 2395-2399.

19. Mishra R, Jana A, Panday AK, Choudhury LH (2019) Synthesis of spirooxindoles fused with pyrazolo-tetrahydropyridinone and coumarin-dihydropyridine-pyrazole tetracycles by reaction medium dependent isatin-based multicomponent reactions. New J Chem 43 :2920-2932.
20. Yang L, Zhao J, Yang X, Chen M, Xue Y, et al. (2019) Effects of solvents on the DACBO-catalyzed vinylogous Henry reaction of isatin with 3,5-dimethyl-4-nitroisoxazole "on-water" and in solution from QM/MM MC simulations. Rsc Advances 9: 4932-4941.

21. Yin C, Xu C, Yu W, Jia Y, Sun W, et al. (2019) Synthesis of a novel isatin and ethylenediamine modified resin and effective adsorption behavior towards Orange G. Rsc Advances 9: 801-809.

22. Hewawasam PM, NA (1994) A General Method for the Synthesis of Isatin: Preparation of Regiospecifically Functionalized Isatin from Anilines. Tetrahedron Letter 35(40): 7295-7306.

23. Magnus NAD WD, Nevill CR, Wepsiec s (2006) Synthesis of Imidazole Based p38 MAP (Mitogen-Activated Protein) Kinase Inhibitors under Buffered Conditions. J P Org Proc Res Develop 10(3): 545-556.

24. Papeo GPH, Broghi D, Varasi (2005) ANew Glycociamidine Ring Precursor: Syntheses of (Z)-Hymenialdisine, (Z)-2 Debromohymenialdisine, and $( \pm)$-endo-2-Debromohymenialdisine. M Org Lett 7(25): 5641.

25. Karale BK, Takate SJ, Salve SP, Zaware BH, Jadhav SS, et al. (2015) Synthesis and Antibacterial Screening of Novel Fluorine Containing Heterocycles. Orient J Chem 31: 307-315.

26. Nain S (2014) Recent Advancement in Synthesis of Isatin as Anticonvulsant Agents: A Review. Med Chem 4(4): 1-12.

27. Khalid Mohammed Khan, Momin Khan, Muhammad Ali, Muhammad Taha, Saima Rasheed, et al. (2009) Synthesis of bis-Schiff bases of isatins and their antiglycation activity. Bioorganic \& Medicinal Chemistry 17(22): 7795-7801.

28. Kassab SH G, Eid N, Amin K, El-Gendy, Sridhar SK, et al. Saravanan M; Ramesh A Eur (c) Singh, U. K.; Pandeya SN; Singh A; Srivastava BK; Pandey, Int. M ((a) 2010 (b) 2001 (c) 2010) (a) A Nucleosides, Nucleotides Nucleic Acids (b) J Med Chem (c) J Pharm Sci Drug Res (a)29 (b) 36 (c) 2:(a)72 (b) 615 (c) 151.

29. Quenelle DK, K; Kern Jiang, T; Kuhen KL Wolff, K; Yin H; Bieza K Caldwell J; Bursulaya B; Tuntland T; Zhang K; Karanewsky, D Bioorg (c) Jarrahpour A; Khalili D; DeClercq E; Salmi C; Brunel, ((a) 2006 (b) 2006 (c) 2007). (a) E Antiviral Res (b) (c) (b) Med Chem Lett (c) J M Molecules (a) 71 (b) 16 (c) 12:(a) 24 (b) 2109 (c) 1720

30. Bal TRA B; Yogeeswari P; Sriram D Lett (b) Sriram D; Yogeeswari P; Myneedu NS; Saraswat V Bioorg (c) Pandeya, SN; Sriram, D; Nath, G; De Clercq, E Eur ((a) 2005 (b) 2006 (c) 2000). (a) Bioorg Med Chem (b) Med Chem Lett (c) J M Molecules (a) 15 (b) 16 (c) 35:(a) 4451 (b) 2127 (c) 4249 .

31. Amal Raj AR R; SrideviKumari MR; Raman N Bioorg; Rodríguez-Argüelles MC; Mosquera-Vázquez S; Tourón-Touceda P; Sanmartín-Matalobos J; García-Deibe AM; Belicchi-Ferrari M; Pelosi G; Pelizzi C; Zani FJ Inorg (c) Dandia A; Singh R; Khaturia S; Mérienne C; Morgant GL ((a) 2003 (b) 2007 (c) 2006). (a) Med Chem (b) Biochem (c) Med Chem (a) 11 (b) 101 (b) 14 (a) 407 (b) 138 (c) 2409

32. Verma MP SN; Singh KN; Stables JP (2004) Acta Pharm 54: 36-49.

33. Gürsoy AK, N Eur (2003) J Med Chem 38: 625-633.

34. Karalı NG A; Kandemirli F; Shvets N; Kaynak FB; Özbey S; Kovalishyn V; Dimoglo A Bioorg, Feng LS; Liu ML; Wang B; Chai Y; Hao XQ; Meng S; Guo HY Eur (c) Sriram D; Yogeeswari P; Basha JS; Radha DR; Nagaraja V Bioorg ((a) 2007 (b) 2010 (c) 2005) (a) Med Chem (b) J Med Chem (c) Med Chem (a) 15 (b) 45 (c) 13:(a) 5888 (b) 3407 (c) 5774.

35. Sridhar SKR, A Biol (2001) Pharm Bul 24:1138-1149.

36. Rang HP DM, Ritter JM, Flower RJ (2007) Rang and Dale's Pharmacolgy, 6th edition Churchil Livingstone Elesevier 538: 670-681.

37. Varma RS PR (1982) Indian J Pharm Sci. 46: 132-135 
38. Sarangapani M SK, Srinivas A (2010) J Chem Pharm Res 2: 220-225.

39. Chiyanzu I CC, Smith PJ, Lehman J Bioorg (2005) Design, synthesis and anti-plasmodial evaluation in vitro of new 4-aminoquinoline isatin derivatives. Med Chem Lett 13(9): 3249-3261.

40. Mitscher LA BW (1998) A search for novel chemothe-rapy against tuberculosis amongst natural products. Pure \& Appl Chem 70(2): 365371.

41. Sriram D YP, Gopal G Eur (2005) Synthesis, anti-HIV and antitubercular activities of lamivudine prodrugs. J Med Chem 40(12): 1373-1376.

42. Jain SK P, Bhagat S, Jain M, Sakhuja R (2005) Phosphorus, Sulfur, Silicon Relat Elem 180: 1820-1829.

43. G Smmaiah GBAMS (2011) Synthesis and biological activity of 2-amino bonzoic acid (2-oxo-1, 2 dihydro-indole-3-ylidene)-hydrizieds. Journal of Advanced Pharmaceutical Sciences 1: 11-121.

44. Xie X, Y JL (2007) Chemical Reagent 29: 25-34.

45. Liu C, Y ZQQ, Li J H (2001) Chemical Reagents 23: 335-344.

46. Li Z, XYL (2007) Journal of Northwest Normal University (Natural Science) 43: 46-57.

47. He B, J SHF (2007) Chinese Journal of Synthetic Chemistry 15: 356-365.

48. Idan C EH (2003) Bioorganic \& Medicinal Chemistry Letters 13: 35163527.

49. UK Singh SNP, A Singh BK, Srivastava M Pandey (2010) Synthesis and Antimicrobial Activity of Schiff's and N-Mannich Bases of Isatin and Its Derivatives with 4-Amino-N-Carbamimidoyl Benzene Sulfonamide. International Journal of Pharmaceutical Sciences and Drug Research 2(2): 151-154.

50. Voronin V, Petrova V, Leksin C, Shemeryankin D1217 (1976) Methods for Synthesis of 5- nitro 8-HydroxyQuinoline. J Chem Heter Comp 21: 1-5.

51. Verma M, Pandeya SN, Singh KN, Stables (2004) JP Acta Pharm 54: 36 49.

52. Sarkisyan MG s (2004) Informatsionnye tekhnologii i upravlenie (Information Technologies and Geverning 170: 1-11.

53. Chinnasamy Rajaram Prakash SR, Govindaraj Saravanan (2010) Synthesis, Characterization and anticinvalutant activity of novel Schiff base of isatin derivatives. International Journal of Pharmacy and Pharmaceutical Sciences 2: 177-181.

54. Hassaan AMA (1990) Transit Met Chem 15: 283-285.

55. Hassaan AMA (1997) Indian J Chem 36: 241-243.

56. M PFDaR (1984) J Heterocycl Chem 21: 278-289.

57. Pandeya SN, S D, Nath G, de Clercq E (2000) Synthesis, antibacterial, antifungal and anti HIV evaluation of schiff and mannich bases of isatin and its derivatives with triazole. Arzneimittel Forsch 50(1): 55-59.

58. Khalili AJaD (2007) Synthesis of some mono- and bis-spiro-b-lactams of benzylisatin. Tetrahedron Letter 48(40): 7140-7143.

59. Garden SJT JC, da Silva LE, Pinto AC (1998) A convenient methodlogy for the N-alkylation of isatin compounds. Synth Commun 28(9): 1679-1689.

60. Harrison RW J (2001) Adv Agr 73: 65-108.

61. Hausinger HLTMaRP (1989) Microbial ureases: significance, regulation and molecular characterization. Micro-biological Reviews 53(1): 85108.

62. HL T, Mobley MDI, RP Hausinger (1995) Molecular biology of microbial ureases. Microbiological Reviews 59(3): 451-480.

63. S Vassiliou AG, P Kosikowska, A Yiotakis, PKafarski, L Berlicki, et al. (2008) Design, synthesis, and evaluation of novel organophosphorus inhibitors of bacterial ureases Journal of Medicinal Chemistry. 51(8): 5736-5744.

64. NC Ha STO, J Y Sung, Jae Young Sung, Kyeung Ah Cha, Mann Hyung Lee, et al. (2001) Supramolecular assembly and acid resistance of Helicobacter pylori urease. Nature Structural \& Molecular Biology 8: 505-509.

65. S Benini WRR, KS Wilson, S Miletti, S Ciurli, S Mangani, et al. (1999) A new proposal for urease mechanism based on the crystal structures of the native and inhibited enzyme from Bacillus pasteurii: why urea hydrolysis costs two nickels. Structure 7(2): 205-216.

66. C Gripenberg-Lerche LZ, P Ahtonen, P Toivanen, M Skurnik (2000) Construction of urease-negative mutants of Yersinia enterocolitica serotypes 0:3 and 0:8: role of urease invirulence and arthritogenicity I. nfection and Immunity 68: 942-947.

67. XinLi, Harry L, TMobley (2002) Vaccines for Proteus mirabilis in urinary tract infection. International Journal of Antimicrobial Agents 19(6): 461465 .

68. Arshad M, Jadoon M, Iqbal Z, Fatima M, Ali M, et al. (2017) Synthesis, molecular structure, quantum mechanical studies and urease inhibition assay of two new isatin derived sulfonylhydrazides. J Mol Struct 1133: 80-89.

69. Singh A, Casey KD, King WD, Pescatore AJ, Gates RS, et al. (2009) Efficacy of urease inhibitor to reduce ammonia emission from poultry houses. Journal of Applied Poultry Research 18(1): 34-42.

70. Amin MI, MS Hughes, RW Khan, SA Reynolds, PA Enne, et al. (2010) Mechanochemical synthesis and in vitro anti-Helicobacter pylori and urease inhibitory activities of novel zinc(II)-famotidine complex. J Enzyme Inhib Med Chem 25(3): 383-390.

71. OUR Abid, TMB, FI Ali, Shahzad Ahmed, Abdul Wadood, et al. (2010) Identification of novel urease inhibitors by high-throughput virtual and in vitro screening. ACS Medicinal Chemistry Letter 1(4): 145-149.

72. MA Aslam SUM, M Shahid, Mohammad Shahid, Aamer Saeed, Jamshed Iqbal, et al. (2011) Synthesis, biological assay in vitro and molecular docking studies of new Schiff base derivatives as potential urease inhibitors. European Journal ofMedicinal Chemistry 46(11): 5473-5479.

73. TC Kuhler JF, NA Bergman, J Weilitz, A Lee, H Larsson, et al. (1995) Structure-activity relationship of omeprazole and analogues as Helicobacter pylori urease inhibitors. Journal of Medicinal Chemistry 38(25): 4906-4916.

74. H Kogen KT, M Arai, E Minami, K Masuda, T Akiyama, et al. (1999) A highly stereoselective synthesis of plaunotol and its thiourea derivatives as potent antibacterial agents against Helicobacter pylori. Bioorganic and Medicinal Chemistry Letters 9(10): 1347-1350.

75. S Odake TM, M Tsuchiya, L Imamura, K Kobashi (1994) Inhibition of Helicobacter pylori urease activity by hydroxamic acid derivatives. Biological and Pharmaceutical Bulletin 17(10): 1329-1332.

76. K Nagata HS, T Iwahi, T Shimoyama, T Tamura (1993) Potent inhibitory action of the gastric proton pump inhibitor lansoprazole against urease activity of Helicobacter pylori, unique action selective for $\mathrm{H}$. pylori cells. Antimicrobial Agents and Chemotherapy 37(4): 769-774.

77. MJ Todd, RP Hausinger (1989) Competitive inhibitors of Klebsiella aerogenes urease. Mechanisms of interaction with the nickel active site. The Journal of Biological Chemistry 264(27): 15835-15842.

78. W SFaraci, BVY, D O’Rourke, RW Spencer (1995) Inhibition of Helicobacter pylori urease by phenyl phospho rodiamidates:mechanismof action. Bioorganic andMedicinal Chemistry 3(5): 605-610.

79. AJ Pope CDNT, B Rushant, S Richardson, M Mcvey, J Hills, et al. (1998) Effect of potent urease inhibitor, fluorofamide, on Helicobacter sp. in vivo and in vitro." Digestive Diseases and Sciences 43: 109-119. 
80. JB Park LI, K Kobashi (1996) Kinectic studies of Helicobacter pylori urease inhibition by a novel proton pump inhibitor, rabeprazole. Biological and Pharmaceutical Bulletin 19(2): 182-187.

81. S Uesato YH, M Nishino, Y Nagaoka, H Kuwajima (2002) N-substituted hydroxyureas as urease inhibitor. Chemical and Pharmaceutical Bulletin 50(9): 1280-1282.

82. Bremner LG, BaJM (1973) Effects of substituted p-benzoquinones on urease activity in soils. Soil Biology and Biochemistry 5(6): 847-853.

83. Z Amtul AUR, RA Siddiqui, MI Choudhary (2002) Chemistry and mechanism of urease inhibition Current Medicinal Chemistry 9(14): 1323-1348.

84. Jyothi KSN, Hemalatha P, Challa S (2011) Evaluation of $\alpha$-amylase inhibitory potential of three medicinally important traditional wild food plants of India 5(2): 95-99.

85. Rhabasa LR CJDR, Ferrannini E, Keen H, Zimmet P (2004) Alphaglucosidase inhibitors ( $3^{\text {rd }} \mathrm{edn}$.). In International textbook of diabetes mellitus John Wiley UK 1: 1-13.

86. SE I (2002) Oral antihyperglycemic therapy for type 2 diabetes. scientific review JAMA 287(3): 360-372

87. Samantha J Venable, Diane S Aschenbrenner H, MD Lippincott Williams, Wilkins (2000) Drug Therapy in Nursing ISBN: 0-7817-4839-7819.

ISSN: 2574-1241

DOI: 10.26717/BJSTR.2020.30.004991

Tariq Aziz. Biomed J Sci \& Tech Res

(C) $(9)$ This work is licensed under Creative

Submission Link: https://biomedres.us/submit-manuscript.php
88. Cheng AYY FI (2005) Oral antihyperglycemic therapy for type 2 diabetus mellitus. Canadian medicinal association 172: 213-226.

89. Hatano T, H Kagawa, T Yasuhara, T Okudas (1988) Two new flavonoids and other constituents in licorice root: their relative astringency and radical scavenging effects. Chem Pharm Bull 36(6): 1090-2097.

90. Halliwell H (1994) Free radicals, antioxidants and human disease: Curiosity, cause or consequence? Lancet 344 (8924): 721-724.

91. Halliwell BaJMCG (1985) Free radicals, ageing and disease, Free radicals in Biology and Medicine. Clarendron Press Oxford 2: 279-315.

92. Hertog MGF E J, Hollman PC Katan, MB Kromhout D Lancet (1993) 342: 1001-1007.

93. Moure AC J, Franco D, Dominguez M, Sineiro J, Dominguez H, et al. (2001) JFood Chem 72: 138-145.

94. Hollman PCH MG (1996) Food Chem 57: 32-43.

95. Bakır T, Sayiner H, Kandemirli F (2018) Experimental and theoretical investigation of antioxidant activity and capacity of thiosemicarbazones based on isatin derivatives 193: 493-499.

$\begin{array}{ll}\text { BIOMEDICAL } & \text { Assets of Publishing with us } \\ \text { RESEARCHES } & \text { - Global archiving of articles } \\ \text { - Immediate, unrestricted online access } & \text { - Rigorous Peer Review Process } \\ & \text { - Authors Retain Copyrights } \\ & \text { https://biomedres.us/ }\end{array}$

